\title{
Field study for the effectiveness of some plants leaf extracts against insect Eutectona macheralis or Teak skeletonizer in forest nursery of Indore, Madhya Pradesh
}

\author{
Hemant Pathak ${ }^{1}$, Saurabh Maru ${ }^{2}$, Satish Chandra Silawat ${ }^{1}$ \\ ${ }^{1}$ Forest Research and Extension Circle, Indore, Madhya Pradesh, India \\ ${ }^{2}$ Laboratory of Pharmacology, Department of Pharmacy, Shri G S Institute of Technology and Science, Indore, Madhya Pradesh, India
}

Email address:

Hemantpathak777@gmail.com (H. Pathak)

\section{To cite this article:}

Hemant Pathak, Saurabh Maru, Satish Chandra Silawat. Field Study for the Effectiveness of Some Plants Leaf Extracts against Insect Eutectona Macheralis or Teak Skeletonizer in Forest Nursery of Indore, Madhya Pradesh. American Journal of Agriculture and Forestry. Vol. 2, No. 4, 2014, pp. 110-113. doi: 10.11648/j.ajaf.20140204.12

\begin{abstract}
The naturally occurring pesticides thus appear to have a prominent role in the development of future economical pesticides not only for agricultural and forestry crop productivity but also for the safety of the environment and public health. The harmful environmental implications of the synthetic pesticides have compelled to search for some alternative methods. This lead to increased development of compounds based on the models of naturally occurring toxins of biological origin, having various biological activities. This includes plant extract, which are now known because they are environmentally harmless and host specific. These different concentrations of plant extracts viz. Annona sqamosa leaf extract, Lantana camara leaf extract, Albizzia lebbeck leaf extract were tested for feeding inhibition properties against Eutectona macheralis insect larvae on host plant Tectona grandis. Prepared leaf extracts were tested in field condition and the most effective concentration has been worked out.
\end{abstract}

Keywords: Eutectona Macheralis, Tectona Grandis and Leaf Extacts

\section{Introduction}

Unintentional poisonings kill an estimated 355000 people globally each year (The world health report 2003). In developing countries - where two thirds of these deaths occur - such poisonings are associated strongly with excessive exposure to, and inappropriate use of, toxic chemicals. In many such settings, toxic chemicals may be emitted directly into soil, air, and water - from industrial processes, pulp and paper plants, tanning operations, mining, and unsustainable forms of agriculture - at levels or rates well in excess of those tolerable to human health.

Acute exposure to pesticides can lead to death or serious illness. Chronic pesticide exposure is most often a problem in the occupational setting, particularly among poor rural populations where men, women, and children all work and live in close proximity to fields and orchards where chemicals are applied and stored. Long-term exposure to pesticides can increase the risk of developmental and reproductive disorders, immune-system disruption, endocrine disruption, impaired nervous-system function, and development of certain cancers. Children are at higher risk from exposure than are adults (Human development report 1998).

The production of pesticides started in India in 1952 with the establishment of a plant for the production of BHC near Calcutta, and India is now the second largest manufacturer of pesticides in Asia after China and ranks twelfth globally [1]. There has been a steady growth in the production of technical grade pesticides in India, from 5,000 metric tons in 1958 to 102,240 metric tons in 1998. In 1996-97 the demand for pesticides in terms of value was estimated to be around Rs. 22 billion (USD 0.5 billion), which is about $2 \%$ of the total world market.

The pattern of pesticide usage in India is different from that for the world in general. As can be seen in Figure, in India $76 \%$ of the pesticide used is insecticide, as against $44 \%$ globally. The use of herbicides and fungicides is correspondingly less heavy. The main use of pesticides in India is for cotton crops $(45 \%)$, followed by paddy and wheat [2].

Thus there is increasing need to find pesticides with selective toxicity to pest and safe to humans and animals. 
The use of botanical insecticides/Biopesticides may serve as suitable alternative as they are relatively safe, degradable and economical (abundantly available in nature). Biopesticides are derived from natural materials such as animals, plants, bacteria, and certain minerals widely used for controlling insects and disease causing pathogens. Though several plants from different families have been reported for their pesticidal activity, only a few botanicals have moved from the laboratory to field use. In present study we are going to observe the effect of biopesticide formulations on feeding inhibition properties against Eutectona macheralis insect larvae on host plant Tectona grandis.

\section{Methodology}

\subsection{Host Plant}

Tectona grandis L.f. is a large deciduous tree with a rounded crown and, under favorable conditions, a tall clean cylindrical bole of more than $25 \mathrm{~m}$. Leaves are broad, elliptical or obovate and usually 30 to $60 \mathrm{~cm}$ long. Over most of its range, teak occurs in moist and dry deciduous forests. Teak (Tectona grandis L.f.) is one of the world's premier hardwood timbers, rightly famous for its mellow color, fine grain and durability. It occurs naturally only in India, Myanmar and Thailand, and it is naturalized in Java, Indonesia. Although relatively unimportant in terms of the volume of world timber production, because of its strength and aesthetic qualities teak is the tropical hardwood most in demand for a specific market of "luxury" applications including furniture, shipbuilding and decorative building components. It is thus of major importance in the forestry economies of its main producing countries [3].

The leaf of Tectona grandis L.f. was observed to have damage of mesophyll tissue on surface of leaf and Skelton of leaf observed. The insect caterpillars of leaf skeltonizer or Eutectona Macheralis were responsible for damage of leaf mesophyll tissue. Due to damage of mesophyll tissue plant leaves were unable to photosynthesis process. Further leaves were dry and discarded.

\subsection{Collection of Test Plants Material}

Sample of test plants viz. Annona squamosa L., Lantana camara (L.) Moldenke., and Albizzia lebbeck (L.) Benth., were collected from different places of Indore district and identified. Annona squamosa L. plant contains aporphine alkaloids, carvone, linalool,limonene squamosin [4]. The samples containing leaves of the selected plant materials were air-dried for 6-7 days. After complete drying the plant parts were pulverized into powder with the help of mortar and pestle. The plant material was extracted by Soxhlet extraction method.

\subsection{Soxhlet Extraction}

The ordinary method of extraction was not efficient to yield good amount of active principle of the plant material.
To extract more active principle from all the plant materials, Soxhlet extraction was used. Known amount $(50 \mathrm{~g})$ of plant material of each species was filled into the Soxhlet apparatus. A cotton plug was used at the place of thimble to stop the entry of the crude material into the siphoning tube. The required solvent (ethanol/methanol) was filled up five times more than total amount of the sample material into the flask of the apparatus. The apparatus was then connected with the water supply to the condenser. The temperature of the heating mantle was maintained. The process was carried out for 5 to 6 hours for each sample. The extract was transferred to Petri plates and solvent was allowed to evaporate [5].

The evaporated material was weighed and mixed with neem oil based emulsion. Neem oil based emulsion was a mix. Emulsion of neem seed oil $(8 \mathrm{ml})$, liquid soap $(4 \mathrm{ml})$ and water (2L). $2.5 \mathrm{gm}$ of plant part extract of each species in $10 \%$ different solvent mixed with $250 \mathrm{ml}$ neem oil based emulsion. Different types of formulation were fill up in different spray pump and sprayed on host plant species.

\subsection{Treatment (Process of Dose Administration)}

The dose were prepared in glass jars and filled in spring bottles. The formulation was sprayed on selected plants in a month of (August - September). This is the period, usually atmospheric temperature is normal but during the present study the Moisture was also present in air. During our trials test plants were exposed to ample sunlight regularly. The weather was rainy. These are optimum condition for growth of insect and pest.

In field trial, treatments of formulation on host plants were given in regular interval of 7 and 15 days from first day of treatment. The trials were started with leaf Soxhelt Ethanol/ Methanol extract of Annona, Lantana and Albizzia plants on host Tectona grandis L.f..

\section{Result and Discussion}

The results of the effect of ethanol/methanol extracts of three plants with neem oil to control teak skletonizer or Eutectona macheralis presented in Table 1. Effects of treatments on Eutectona macheralis evaluated from the reduction in numbers of infected leaves after application of treatments. The analysis of variance for the effects of treatments generally indicated the plant extracts treatments significantly reduced infected leaves than the untreated during the trial seasons. Table1 reveals that Ethanolic leaf extract of Annona squamosa L., Lantana camara (L.) and Albizzia lebbeck (L.) Benth. with Neem oil based solution found to be effective on infected plant and Methanolic leaf extract of Annona squamosa L., Lantana camara (L.) and Albizzia lebbeck (L.) Benth. with Neem oil based solution found to be more effective compare to ethanol extract, on infected leaves. Only neem oil based emulsion also found to be effective. Neem oil contains azadirachtin, nimbidin, limonoids, terpenoids, coumarins, sulphur compounds, phenolics etc., [6] which have proven value against many 
insect larvae, Leaf folder, aphids, Jassids, fruit borer and stem borer insect [7].

This is the first time when the effect of Annona squamosa $L$. leaf extract against teak skletonizer larvae was proved in the field study. Earlier it has been studied in laboratory and reported that both topical and leaf applications of cold alcohol extract of Annona squamosa L. seeds are highly effective in controlling the lepidopteran pest, S. litura. [8]. This is also the first time when Annona squamosa $L$. leaf extract was used in combination with neem oil in the field studies on economically important trees. The present study indicated that the leaves of Annona squamosa $L$. reported to contain annonins which is toxic or repellent for insect larvae. The insecticidal activity of the seed extracts of $A$. squamosa is attributable to annonins (i.e., annonin I = squamocin), adjacent bis-tetrahydrofuran (THF) ring acetogenins studied [9]. Table 1 revealed that Methanol extract of Annona squamosa L. leaves found more effective than Ethanol as Methanol has been inhibited by $1.8 \%$ infected leaf compare to $1.4 \%$ increase by Ethanol extract. Insecticidal activity of ethanol extract of Annona squamosa $L$. leaves also reported [10]. A. squamosa leaf extract with petroleum ether effected on Eutectona macheralis larvae [11].

Table 1. Treatment on Tectona grandis with Soxhlet leaf Ethanol/Methanol Extract of selected plant species

\begin{tabular}{|c|c|c|c|c|c|c|c|c|}
\hline \multirow{2}{*}{$\begin{array}{l}\text { S. No. of } \\
\text { block }\end{array}$} & \multirow{2}{*}{ Treatment Type } & \multicolumn{3}{|c|}{$\begin{array}{c}\text { Total No. of leaves in } 10 \\
\text { plants of each block }\end{array}$} & \multicolumn{3}{|c|}{$\begin{array}{c}\text { Total No. of Infected leaves in } 10 \text { plants } \\
\text { of each block (\%) }\end{array}$} & \multirow{2}{*}{$\begin{array}{c}\text { Effect of treatment } \\
\text { on infected leaves } \\
\text { in \% }\end{array}$} \\
\hline & & $\mathbf{A}$ & B & $\mathrm{C}$ & $\mathbf{A}$ & B & C & \\
\hline 1. & 1.Control & 83 & 84 & 70 & $\begin{array}{c}4 \\
(4.8)\end{array}$ & $\begin{array}{c}8 \\
(9.5)\end{array}$ & $\begin{array}{c}16 \\
(22.8)\end{array}$ & 18 increase \\
\hline 2. & 2.Base sol. & 65 & 67 & 73 & $\begin{array}{c}9 \\
(13.8)\end{array}$ & $\begin{array}{c}4 \\
(5.9)\end{array}$ & $\begin{array}{c}22 \\
(30.1)\end{array}$ & 16.3 increase \\
\hline 3. & $\begin{array}{l}\text { 3.Base sol. with Annona leaf extract } \\
\text { in Ethanol }\end{array}$ & 51 & 56 & 69 & $\begin{array}{c}6 \\
(11.7)\end{array}$ & $\begin{array}{c}4 \\
(7.14)\end{array}$ & $\begin{array}{c}9 \\
(13.1)\end{array}$ & 1.4Increase \\
\hline 4. & $\begin{array}{l}\text { 4.Base sol. with Annona leaf extract } \\
\text { in Methanol }\end{array}$ & 60 & 61 & 61 & $\begin{array}{c}7 \\
(11.6)\end{array}$ & $\begin{array}{c}6 \\
(9.8)\end{array}$ & $\begin{array}{c}6 \\
(9.8)\end{array}$ & 1.8Decrease \\
\hline 5. & $\begin{array}{l}\text { 5.Base sol. with Lantana leaf } \\
\text { extract in Ethanol }\end{array}$ & 72 & 78 & 73 & $\begin{array}{c}9 \\
(12.5)\end{array}$ & $\begin{array}{c}6 \\
(7.6)\end{array}$ & $\begin{array}{c}10 \\
(13.6)\end{array}$ & 1.1 Increase \\
\hline 6. & $\begin{array}{l}\text { 6.Base sol. with Lantana leaf } \\
\text { extract in Methanol }\end{array}$ & 70 & 72 & 73 & $\begin{array}{c}9 \\
(12.3)\end{array}$ & $\begin{array}{c}8 \\
(11.1)\end{array}$ & $\begin{array}{c}7 \\
(9.5)\end{array}$ & 2.8Decrease \\
\hline 7. & $\begin{array}{l}\text { 7.Base sol. with Albizzia leaf } \\
\text { extract in Ethanol }\end{array}$ & 69 & 72 & 75 & $\begin{array}{c}10 \\
(14.4)\end{array}$ & $\begin{array}{c}11 \\
(15.2)\end{array}$ & $\begin{array}{c}11 \\
(14.6)\end{array}$ & 0.2 Increase \\
\hline 8. & $\begin{array}{l}\text { 8.Base sol. with Albizzia leaf } \\
\text { extract in Methanol }\end{array}$ & 72 & 60 & 56 & $\begin{array}{c}22 \\
(30.5)\end{array}$ & $\begin{array}{c}18 \\
(30)\end{array}$ & $\begin{array}{c}17 \\
(30.3)\end{array}$ & 0.2 Decraese \\
\hline
\end{tabular}

Table 1 revealed that Methanol extract of Lantana camara (L.) leaves found more effective than Ethanol as Methanol has been inhibited by $2.8 \%$ infected leaf compare to $1.1 \%$ increase by Ethanol extract. Lantana camara (L.) leaf extract found effective, [12] mentioned Antifungal property of $L$. camara and $O$. sanctum against Drechslera sorokiniana were reported. The above discussed effects of crude aqueous extract of $L$. camara leaves may be due to the active toxic group like Lantadene present in the leaves. The possibility of toxic effects of some other chemical groups such as lantoniside, linaroside and carmarinic acid cannot be ruled out and has to be elucidated in future along with some other bioactivities [13]. Leaf applications of crude aqueous extract of $L$. camara leaves are highly effective in controlling the lepidopteran pest $S$. litura reported [14]. Adulticidal activity of essential oil of Lantana camara (L.) leaves against mosquitoes also reported [15].

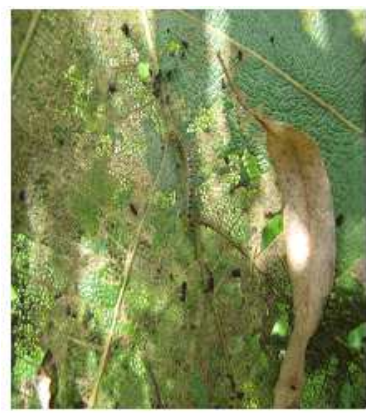

Catterpilar of Eutectona macheralis.

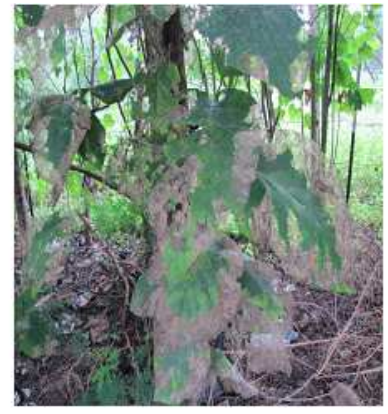

Effect of Eutectona macheralis on Tectona grandis leaf.

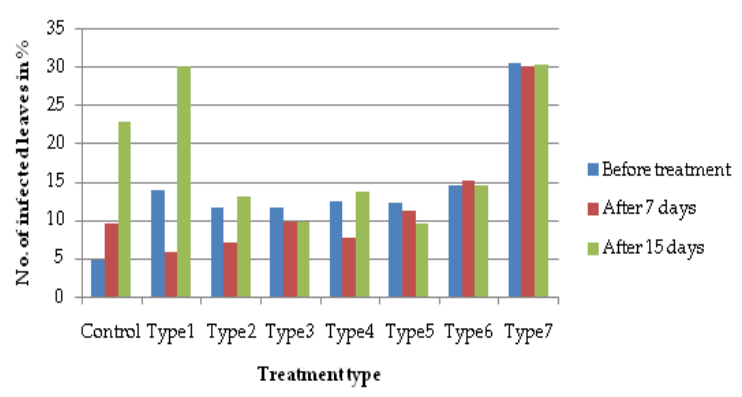

Graph 1. Treatment on Tectona grandis with soxhlet leaf Ethanol/Methanol Extract 
The Methanol extract of Albizzia lebbeck (L.) Benth. leaves found more effective than Ethanol as Methanol has been inhibited by $0.2 \%$ infected leaf compare to $0.2 \%$ increase by Ethanol extract. Albizzia lebbeck (L.) Benth. leaf extract found least effective which resulted that the plant species have some insecticidal properties. It was also reported [5] Methanolic extract of $A$. lebbeck seeds, leaves and bark contain alkaloids and triterpens that may be affect 20-hydroxy ecdyson which is triterpen. Also phytoecdysteroids are class of triterpenoides that composed of saponine, phytosterols and phytoecdysteroids[16]. The plant leaf powders of $W$. somnifera, O. sanctum and $A$. lebbeck possess the property to safeguard the stored chickpea grain [17]. Seeds of Albizzia lebbeck (L.) Benth. have saponins, oleic and linoleic acid[18].

\section{Conclusion}

This plant product is also eco-friendly, easily available and economically viable. Biopesticides considered being safe to natural enemies and free from any residue problem on the crop and in the environment [19]. The use of plant extracts with insecticidal properties has the potential of reducing the effects of insect pests of forest tree and agricultural crops. These can be of importance to the resource-poor farmers in many areas of the developing world. Now we were concluded that the Leaf Extract of test plants found effective against teak skletonizer insect. If these biopesticides produced commercially and farmers are trained for their use there is no doubt that these eco-safe products can replace the hazardous chemicals of the field in coming days.

\section{Acknowledgement}

Authors are thankful to Forest Research and Extension Circle, Indore for conducting experiments.

\section{References}

[1] SC.Mathur, Future of Indian pesticides industry in next millennium. Pesticide Information, 24(4):9-23. (1999).

[2] Md., Aktar wasim, Dwaipayan Sengupta, and Ashim Chowdhury, Impact of pesticides use in agriculture: their benefits and hazards. Interdiscip. Toxicol. 2(1): 1-12. (2009).

[3] D. Pandey and C. Brown Teak: a global overview, Unasylva 201, Vol. 51. (2000).

[4] O. Ekundayo A review of the volatiles of the Annonaceae. J Essent Oil Res. 1: 223. (1989)

[5] Maru et. Al. Anticancer property of Bryophyllum pinnata (Lam.) Oken. leaf on human cervical cancer cells $B M C$ Complementary and Alternative Medicine 12:152012,

[6] Subbalakshmi Lokanadhan, P. Muthukrishnan and
S.Jeyaraman, Neem products and their agricultural applications, J. Biopest, 5 (Supplementary): $72-76$ (2012)

[7] Shiv Narayan Sharma, Zenu Jha, Mahendra Sharan Tiwari, Dinesh Baghel and D.K. Sharma Standardization and Quality Evaluation of Herbal Pesticide African Journal of Basic \& Applied Sciences 2 (5-6): 184-187, (2010).

[8] Pratibha V. Deshmukhe, Ashok A. Hooli and S. N. Holihosur Bioefficacy of cold ethyl alcohol extract of Annona squamosa against Spodoptera litura Fabricius. Journal of Biopesticides 3(1 Special Issue) 271 - 274. (2010).

[9] M. Sahai, S. Singh, Y.K. Gupta, S. Akashi, and R. Yuji, Annonaceous acetogenins from the seeds of Annona squamosa adjacent bis-tetrahydrofuranic acetogenins. Chem. Pharm. Bull. (Tokyo) 42:1163-1174. (1994).

[10] N. Begum, B. Sharma, and R.S. Pandey Evaluation of Insecticidal efficacy of Calotropis procera and Annona squamosa ethanol extracts against Musca domestica. J. Biofertil. Biopestici.; 1:1,.doi.org/10.4172/21556202.1000101. (2010).

[11] P. B. Meshram, Role of some biopesticides in management of some forest insect pests, Journal of Biopesticides 3 (1 Special Issue) $250-252$ (2010).

[12] K.P. Varma, R. Hedge, and S. Kulkarni, In vitro evaluation of phytoextracts and biocontrol agents against Drechslera sorokiniana, In: Asian Congress of Mycology, Plant Patholology, Indian Society of Mycology, Plant pathology, University of Mysore (Abstract), October 1-4, 241. 2002.

[13] N. Kulkarni, K.C. Joshi, and B.N. Gupta, Antifeedant property of Lantana camara var. aculeata and Aloe vera leaves against teak skeletonizer, Eutectona machaeralis Walk. (Lepidoptera: Pyralidae) Entomon, 22: 61-65. (1997).

[14] Pratibha V.Deshmukhe, Hooli A. Ashok and S. N. Holihosur Effect of Lantana camara (L.) on growth, development and survival of tobacco caterpillar. Karnataka J. Agric. Sci., 24 (2): (137-139) (2011).

[15] V.K. Dua, A.C. Pandey and A.P. Dash Adulticidal activity of essential oil of Lantana camara leaves against mosquitoes, Indian J Med Res 131, , pp 434-439 (2010),

[16] A.S. Al-Dahmin, Evaluation of the field efficacy of crude extracts of Albizzia lebbeck (L.)Benth. and Actara insecticide on biological performance of Ommatissus lybicus (Homoptera : Tropiduchidae). Ph.D. Thesis. College of Science, University of Baghdad. (2008).

[17] Sarwar Muhammad some possibilities on the effectiveness of plant powders as grain protectants against cowpea weevil, Callosobruchus maculatus (Fabricius) Walp (Coleoptera: Bruchidae) infestation in chickpea, International journal of Agronomy and Plant Production. Vol., 1 (2), 45-50. (2010)

[18] faisal Mohammed, P.P. Singh and R. Irchhaya review of albizzia lebbek a potent herbal drug, IRJP, 3 (5). (2012)

[19] U. Mukherjee, and H. N. Singh, Eco-friendly approaches to manage Diamond-Back moth, Plutella xylostella (L.) in cauliflower. Journal of Appllied Zoological Reasearch, 17(1): 57 - 60. (2006). 